\title{
Long-term 25-hydroxy vitamin D3 level of patients supplied with total thyroidectomy due to nodular goiter
}

\author{
Nodüler guatr nedenli total tiroidektomili uygulanmış hastaların uzun dönem 25-hidroksi \\ D3 vitamin seviyesi
}

Hacı Bolat, Mustafa Kaçmaz

Gönderilme tarihi:09.09.2021

Kabul tarihi:01.11.2021

\begin{abstract}
Introduction: One of the most important problems developing in patients who have undergone thyroidectomy is hypocalcemia. For this reason, the calcium $(\mathrm{Ca})$ level is screened in patients, but it is not routinely screened for low levels of 25-hydroxy vitamin D3 (25-OH D3), which is found to be associated with many diseases in the postoperative mid-period, in normocalcemic patients who have undergone thyroidectomy.

Material and method: The study included 60 normocalcemic patients (Group 1) who underwent thyroidectomy due to nodular goiter and 170 patients (Group 2) who applied with the suspicion of thyroid disease and who were evaluated as normal and who did not receive $\mathrm{Ca}$ and 25-OH D3 supplements (Group 2). Biochemical hypocalcemia was defined as a corrected Ca level of less than $8.0 \mathrm{mg} / \mathrm{dL}$. 25-OH D3 levels of all patients at the postoperative $12^{\text {th }}$ month were recorded by scanning their Ca levels and routine laboratory tests.

Results: Measurements were made in $12^{\text {th }}$ month postoperatively. The $25-\mathrm{OH}$ D3 levels of the patients in Group 1 were lower than the 25-OH D3 lev els of the patients in Group $2(p<0.001)$. The thyroxine (T4) hormone levels of the patients in Group 1 were higher than the T4 values of the patients in Group $2(p=0.002)$. There was no statistically significant difference between the Ca levels of the patients in Group 1 and Group 2. ( $p>0.05)$. There was no difference between other measurement parameters.

Conclusion: We think that in patients who underwent thyroidectomy due to nodular goiter, their $25-\mathrm{OH}$ D3 levels should be screened in the postoperative period and replaced if necessary.
\end{abstract}

Key words: Thyroidectomy, 25-OH D3, calcium, nodular goiter.

Bolat H, Kacmaz M. Long-term 25-hydroxy vitamin D3 level of patients supplied with total thyroidectomy due to nodular goiter. Pam Med J 2022;15:277-284.

Öz

Giriş: Troidektomi yapılmış olan hastalarda gelişen en önemli problemlerden birisi hipokalsemidir. Bu nedenle hastalarda kalsiyum düzeyi taranmakta, ancak troidektomi yapılmış olan normokalsemik hastalarda, postoperatif orta dönemde birçok hastalıkla ilişkili olduğu tespit edilen, 25-hydroxy vitamin D3 (25-OH D3) vitamin düşüklüğünün bulunup bulunmadığı rutin olarak taranmamaktadır.

Gereç ve yöntem: Çalışmaya nodüler guatr nedeniyle troidektomi uygulanmış normokalsemik 60 hasta ile (Grup 1) troid hastalığı şüphesi ile başvurmuş olup troid ultrasonografisi uygulanmış ve normal olarak değerlendirilmiş olan kalsiyum ve 25-OH D3 vitamin desteği almayan 170 hasta (Grup 2) dahil edildi. Biyokimyasal hipokalsemi, $8.0 \mathrm{mg} / \mathrm{dL}$ 'den az düzeltilmiş kalsiyum seviyesi olarak tanımlandı. Tüm hastaların postoperatif 12 . aydaki D vitamini düzeyleri Ca düzeyleri ve rutin laboratuvar tetkikleri taranarak kayıt altına alındı.

Bulgular: Ölçümler postoperarif 12. ayda yapıldı. Grup 1'de yer alan hastaların 25-OH D3 düzeyleri Grup 2 'de yer alan hastaların 25-OH D3 düzeylerinden düşüktü $(p<0,001)$. Grup 1'de yer alan hastaların tiroksin (T4) hormon düzeyleri Grup 2'de yer alan hastaların T4 değerlerinden yüksekti $(p=0,002)$. Grup 1'de yer alan hastaların kalsiyum Ca düzeyleri ile Grup 2'de yer alan hastaların Ca düzeyleri arasında istatistiksel olarak anlamlı fark yoktu $(p>0,05)$. Diğer ölçüm parameteleri arasında fark yoktu.

Sonuç: Nodüler guatr nedeniyle tiroidektomi yapılan hastalarda postoperatif dönemde 25-OH D3 düzeylerinin taranarak gerektiğinde, replase edilmesi gerektiğini düşünüyoruz.

Anahtar kelimeler: Tiroidektomi, 25-OH D3, kalsiyum, nodüler guatr.

Bolat H, Kaçmaz M. Nodüler guatr nedenli total tiroidektomili uygulanmış hastaların uzun dönem 25-hidroksi D3 vitamin seviyesi. Pam Tıp Derg 2022;15:277-284.

Hacı Bolat, M.D. Department of General Surgery, Omer Halisdemir University Faculty of Medicine, Nigde, Turkey, e-mail: hbolat01@yahoo.com (https://orcid.org/0000-0001-9481-7756)

Mustafa Kaçmaz, M.D. Department of Anesthesiology, Omer Halisdemir University Faculty of Medicine, Nigde, Turkey, e-mail: muskac51@ gmail.com (https://orcid.org/0000-0002-8655-3882) (Corresponding Author) 


\section{Introduction}

Thyroid nodules (TN) are relatively common diseases in the population and are generally benign. The frequency of TN varies according to the region of the nodule, the sensitivity of the imaging methods for the diagnosis of the nodule and the sensitivity of the scanning methods [1]. Thyroid diseases, which have an important place among endocrine system diseases, are four times higher in women than in men, regardless of iodine deficiency. Although the incidence of nodules decreases with age, nodules are detected in approximately half of the population around the age of 60 [2].

Thyroidectomy is a surgical method that is applied in many diseases of the thyroid gland, especially in nodular diseases of the thyroid, and is based on the removal of the thyroid gland. Thyroidectomy was first performed by Theodor Kocher in 1870 [3]. Many methods have been used in the surgical treatment of thyroid. However, total thyroidectomy has become the most preferred method in surgical treatments for both thyroid nodules and endocrine reasons in recent years [4].

25-Hydroxy vitamin D3 (25-OH D3) is a fat-soluble vitamin that is primarily involved in calcium ( $\mathrm{Ca}$ ), phosphate $(\mathrm{P})$ metabolism and bone mineralization, and is a precursor of steroid hormones. It controls all $\mathrm{Ca}$ hemostasis in the endocrine system, $\mathrm{Ca}$ absorption in the intestine and also regulates urinary $\mathrm{Ca}$ excretion and bone metabolism [5].

$25-\mathrm{OH}$ D3 is a fat-soluble vitamin that increases the body's absorption of $\mathrm{Ca}$, magnesium $(\mathrm{Mg})$, and $\mathrm{P}$ and is used for normal bone developmentand maintenance. To maintain a healthy 25-OH D3 level, the circulating level of $25-\mathrm{OH}$ D3 must be greater than $30 \mathrm{ng} / \mathrm{mL}$. Many studies now show an association between 25$\mathrm{OH}$ D3 deficiency and cancer, cardiovascular disease, diabetes, autoimmune diseases, and depression. Therefore, the assessment and management of 25-OH D3 deficiency plays an important role in improving care for patients with this condition [6].

Recent evidence has shown an association between low 25-OH D3 status and autoimmune thyroid diseases such as Hashimoto's thyroiditis and Graves' disease. It has also been reported that 25-OH D3 signaling is impaired in thyroid cancers. Therefore, studies on the possible role of 25-OH D3 in thyroid diseases, including autoimmune thyroid diseases and thyroid cancers, are also being conducted [7].

The aim of our study is to determine whether there is low 25-OH D3 in the postoperative mid-term, and to evaluate the change in thyroid function tests and basic laboratory values in normocalcemic patients who have undergone thyroidectomy and who have only had postoperative Levothyroxine sodium replacement.

\section{Materials and methods}

Patients who applied to the General Surgery Clinic of Nigde Omer Halisdemir University Medical Faculty Training and Research Hospital with the complaint of thyroid disease and had neck ultrasonography imaging for thyroid disease were included in the study. The study was carried out in accordance with the principles of the Declaration of Helsinki, after it was approved with the decision of the ethics committee of Nigde Omer Halisdemir University, dated 12.08.2021 and numbered 2021/74. There were 70 total thyroidectomy patients who underwent total thyroidectomy for nodular goiter in the study group, and 192 healthy individuals in the control group. 10 patients in the study group whose records were scanned and 22 patients in the control group were excluded from the study due to exclusion criteria (Figure 1).

Inclusion criteria in the study group were determined as patients between the ages of 18-80 who underwent total thyroidectomy due to a thyroid nodule, were normocalcemic, did not receive $\mathrm{Ca}$ and $25-\mathrm{OH}$ D3 supplements in the postoperative period, but were euthyroid with thyroid hormone replacement. The control group, on the other hand, was determined as patients between the ages of 18-80, who applied with the suspicion of thyroid disease, who underwent thyroid ultrasonography and were evaluated as normal, and did not receive $\mathrm{Ca}$ and 25-OH D3 supplementation. Biochemical hypocalcemia was defined as a corrected $\mathrm{Ca}$ level of less than $8.0 \mathrm{mg} / \mathrm{dL}$.

Exclusion criteria in both groups were those who received Oral 25-OH D3 supplementation, individuals under the age of 18 and over the age of 80 , those with hyperthyroidism, hypothyroidism, hashimoto thyroiditis, patients with parathyroid adenoma, those receiving 25-OH D3 therapy and Ca replacement 


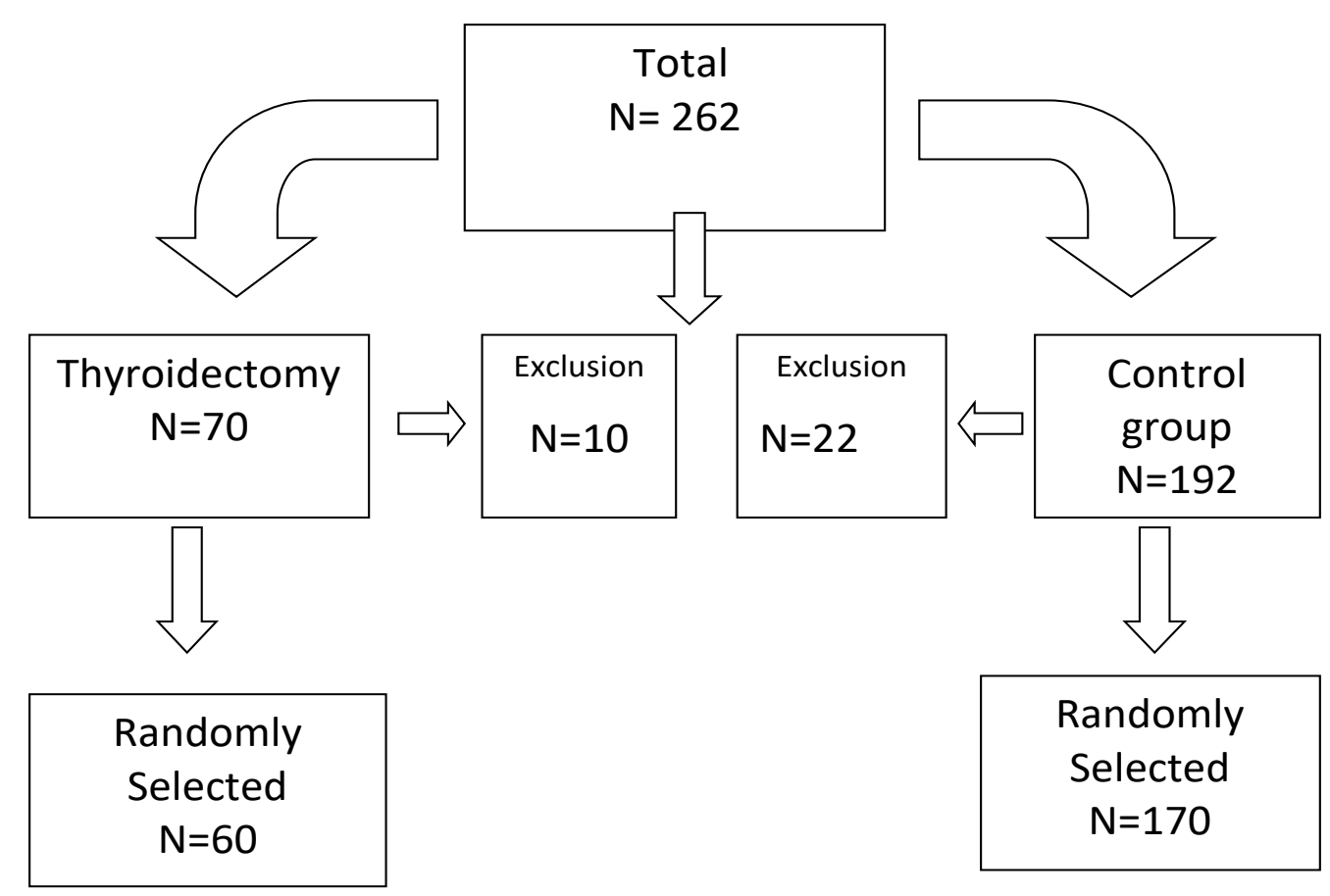

Figure 1. Study overview

therapy, those with malnutrition, and those with gastrointestinal system who underwent surgery were identified.

The patients included in the study were divided into two groups as study (group 1) and control (group 2). Total thyroidectomy was performed in all patients in the study group. Patients were normocalcemic at least one year after the operation. In the control group, there were patients whose age, gender, body mass index (BMI) were similar to the study group and whose physical examination and neck ultrasonography were normal in the same period, but whose 25-OH D3 levels were checked.

The information of the individuals included in the study was collected from the computerbased electronic archive system of our hospital. All patients included in the study had a neck ultrasonography report interpreted by the same radiologist in the same year. At least one year after the operation, blood 25-OH D3 levels and other laboratory data of the patients with total thyroidectomy and the control group included in the study were recorded.

The information about gender, age, weight, $\mathrm{BMI}$, medical treatment for thyroid, and thyroid surgery of the individuals who met the study criteria and were included in the study were recorded. In the thyroid ultrasonography report, whether there was a mass in the thyroid, whether the mass was benign or malignant, and its dimensions were examined. In our study, data on whether the pathology results of patients with total thyroidectomy were malignant or benign and histopathological diagnosis of malignancy were collected and recorded. 25-OH D3 level, free Triiodothyronine (T3), free T4, Thyroid stimulating hormone (TSH) hormones, $\mathrm{Ca}, \mathrm{Mg}$, $\mathrm{P}$, albumin, glucose, creatinine and Glomerular filtration rate (e-GFR) results were recorded in laboratory examination screening.

\section{Statistics}

Statistical analyses were performed by using IBM SPSS for Windows Version 21.0 package program. Numerical variables were summarized as mean \pm standard deviation. The normality of numerical variables was examined using the Kolmogorov Smirnov and Shapiro Wilks test. Independent groups t-test was used to compare normally distributed variables between groups. Mann-Whitney U-test was used for the variables in which normality was not achieved. Pearson's 2 -test and Fisher's exact test were used to compare categorical data between groups.

\section{Results}

There was no significant difference between the groups in terms of age $(p=0.134)$. When evaluated in terms of height, no statistically 
significant difference was found between the groups $(p=0.659)$ and there was no statistically significant difference between the groups in terms of weight $(p=0.219)$. Group 1 consisted of 48 men and 12 women, and group 2 consisted of 140 men and 30 women. When evaluated in terms of gender, there was no statistically significant difference between the groups $(p=0.685)$ Table 1.

When evaluated in terms of laboratory values, the patients in Group 1 were at the 12th postoperative day. There was a statistically significant difference between the 25-OH D3 measurements in the month and the 25-OH D3 measurements of the patients in the control group $(p<0.001)$. There was a statistically significant difference between the T4 hormone levels of the patients in group 1 at the postoperative 12th month and the T4 values of the patients in the control group ( $p=0.002)$. There was no statistically significant difference between the $\mathrm{Ca}$ levels of the patients in group 1 at the postoperative 12th month and the $\mathrm{Ca}$ levels of the patients in the control group $(p>0.05)$ (Figure 2). When evaluated in terms of other measured laboratory values, no statistically significant difference was found between the laboratory values of the patients in Group 1 at the postoperative 12th month and Group 2 ( $p>0.05)$ (Table 2).

While 25-OH D3 deficiency was present in $56.6 \%$ of the patients in Group 1, it was found in only $2.9 \%$ of the patients in Group 2. While the Ca value was sufficient in $90 \%$ of the patients in Group 1, it was within normal limits in $97 \%$ of the patients in Group 2 (Table 3).

Table 1. Age, weight, height, and sex characteristics of groups

\begin{tabular}{|c|c|c|c|c|c|}
\hline & & Group $1 \quad(n=60)$ & Group $2(n=170)$ & & \\
\hline & n (\%) & Mean $\pm S D$ & n (\%) & Mean $\pm S D$ & $p$ \\
\hline Age (yrs) & & $52,6 \pm 12.2$ & & $46.8 \pm 11.1$ & $0.134^{b}$ \\
\hline Height (cm) & & $161.9 \pm 6.4$ & & $162.2 \pm 6.4$ & $0.659^{b}$ \\
\hline Weight (kg) & & $71.7 \pm 9.7$ & & $70.5 \pm 9.2$ & $0.219^{b}$ \\
\hline Sex & & & & & $0.685^{c}$ \\
\hline Male & $48(75)$ & & $140(78.6)$ & & \\
\hline Female & $12(25)$ & & $30(21.4)$ & & \\
\hline
\end{tabular}

Data presented as mean $\pm S D$, median (min-max), and number of patients (\%)

ASA: American Society of Anesthesiologists, MAP: Mean Arterial Pressure, f: female

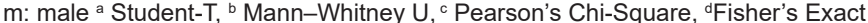

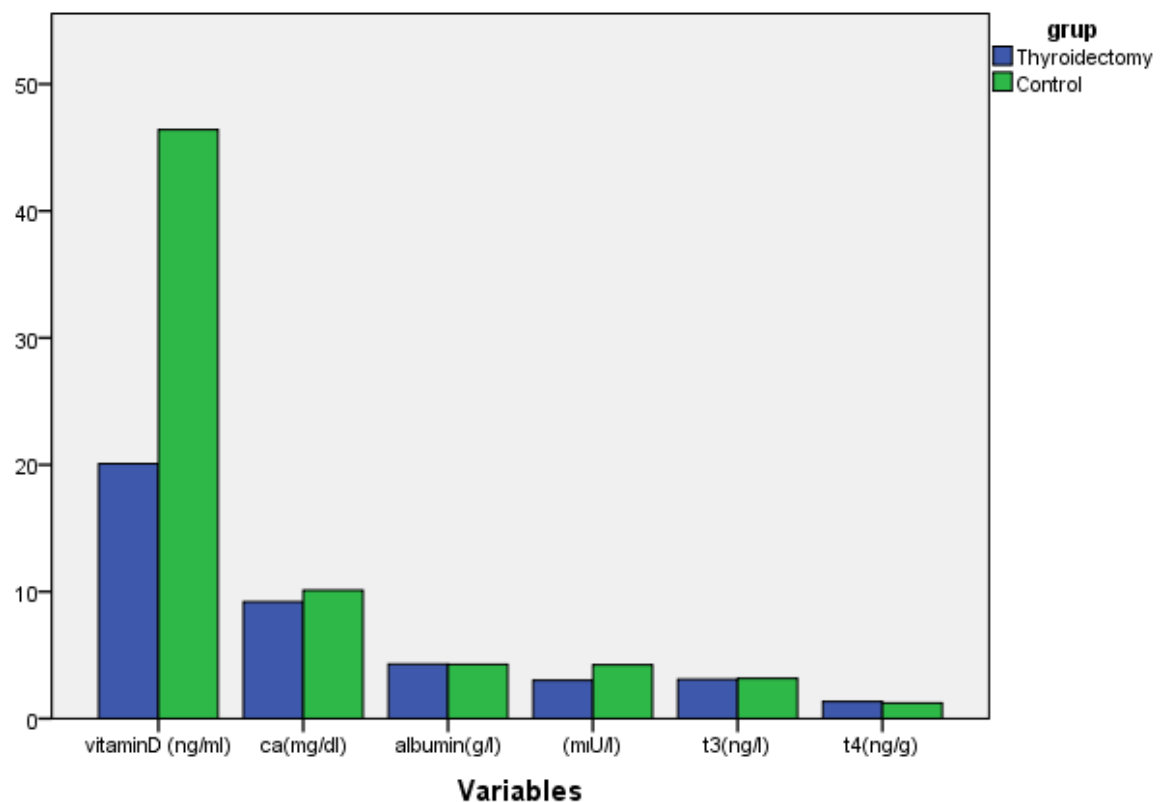

Figure 2. D vit, Ca, Albumin, T3, T4, TSH values between groups 
Table 2. Biochemical results between groups

\begin{tabular}{llll}
\hline & Group 1 $(\mathrm{n}=60)$ & Group 2 $(\mathrm{n}=170)$ & \\
\hline & Mean \pm SD & Mean \pm SD & $\boldsymbol{p}$ \\
Vitamin D & $20.71 \pm 10.45$ & $30.24 \pm 8.51$ & 0.000 \\
Calcium & $9.15 \pm 0.50$ & $9.41 \pm 0.48$ & $0.348^{\mathrm{a}}$ \\
Potassium & $3.67 \pm 0.62$ & $3.55 \pm 0.61$ & $0.405^{\mathrm{b}}$ \\
Magnesium & $2.08 \pm 0.18$ & $2.07 \pm 0.20$ & $0.636^{\mathrm{b}}$ \\
Protein & $7.17 \pm 0.56$ & $7.09 \pm 0.57$ & $0.791^{\mathrm{a}}$ \\
Albumin & $4.35 \pm 0.36$ & $4.26 \pm 0.38$ & $0.610^{\mathrm{b}}$ \\
TSH & $3.67 \pm 4.6$ & $4.58 \pm 11.9$ & $0.591^{\mathrm{b}}$ \\
T3 & $3.03 \pm 0.66$ & $3.13 \pm 0.69$ & $0.815^{\mathrm{a}}$ \\
T4 & $1.33 \pm 0.15$ & $1.25 \pm 0.30$ & $0.002^{\mathrm{b}}$ \\
Glucose & $92.60 \pm 12.59$ & $100.00 \pm 33.16$ & $0.177^{\mathrm{b}}$ \\
Creatinine & $0.75 \pm 0.11$ & $0.81 \pm 0.22$ & $0.686^{\mathrm{b}}$ \\
eGFR & $92.21 \pm 14.61$ & $85.60 \pm 18.26$ & $0.305^{\mathrm{a}}$ \\
\hline
\end{tabular}

Data presented as mean+SD and number of patients (\%)

a 0.591 Student- $T$, b Mann-Whitney $U$, test

Table 3. Percentage of Vitamin D and calcium levels in trodectomy patients

\begin{tabular}{llll}
\hline Variable & Vitamin levels & Group 1 $(\mathbf{n}=60)$ & Group 2 (n=170) \\
\hline Severely Deficient & Vitamin $D<10 \mathrm{ng} / \mathrm{mL}$ & $8(13.3)$ & $0(0)$ \\
Deficient & Vitamin $D<20 \mathrm{ng} / \mathrm{mL}$ & $26(43.3)$ & $5(2.9)$ \\
Insufficient & Vitamin D $<30 \mathrm{ng} / \mathrm{mL}$ & $15(25)$ & $80(47)$ \\
Sufficient & Vitamin D $>30 \mathrm{ng} / \mathrm{mL}$ & $11(18.3)$ & $85(50)$ \\
Low & Calcium $\leq 8 \mathrm{mg} / \mathrm{dl}$ & $6(10)$ & $3(1.7)$ \\
Sufficient & Calcium $\leq 9 \mathrm{mg} / \mathrm{dl}$ & $30(50)$ & $69(40.5)$ \\
Normal & Calcium $\leq 10 \mathrm{mg} / \mathrm{dl}$ & $24(40)$ & $98(57.6)$ \\
\hline
\end{tabular}

Data presented number of patients (\%)

Pathology results of 60 patients in the study group were reported as 9 malignant and 51 as benign. Ca values were similar in benign and malignant groups $(p=0.680)$. However, $25-\mathrm{OH}$ D3 level was significantly lower in patients with malignant pathology $(p=0.008)$ (Table 4).

Table 4. D vit and Ca values according to the results of malignant and benign pathology

\begin{tabular}{llll}
\hline & Benign & Malign & $\boldsymbol{p}$ \\
\hline Vitamin D & $21.62 \pm 10.17$ & $12.69 \pm 5.78$ & 0.008 \\
Calcium & $9.17 \pm 0.64$ & $9.33 \pm 0.47$ & 0.680 \\
\hline Data presented as mean+SD & &
\end{tabular}

\section{Discussion}

It has been reported that in patients who develop biochemical and symptomatic hypocalcemia after thyroidectomy, there is a significant decrease in 25-OH D3 level, and especially in patients with severe $(<10 \mathrm{ng} / \mathrm{mL})$ 25-OH D3 deficiency, there is also significant symptomatic and biochemical hypocalcemia [8]. In our study, we investigated whether there was a decrease in long-term 25-OH D3 levels in patients who continued their lives as normocalcemic after thyroidectomy.

There are reports showing that there is a correlation between 25-OH D3 deficiency and hypocalcemia in the postoperative period, and hypocalcemia deepens as 25-OH D3 level decreases. In this study, it was shown that there was a significant difference in postoperative 
hypocalcemia rates between those with 25$\mathrm{OH}$ D3 levels $>50 \mathrm{nmol} / \mathrm{l}(>20 \mathrm{ng} / \mathrm{ml})$ and those with $<25 \mathrm{nmol} / /(10 \mathrm{ng} / \mathrm{ml})$ [9]. However, studies measuring 25-OH D3 levels in patients who were found to be normocalcemic in the postoperative period after thyroidectomy surgery are very rare. In our study, we observed a significant decrease in 25-OH D3 levels at 12 months after thyroidectomy. This result showed us that 25-OH D3 deficiency, which is associated with many diseases, can be encountered after thyroidectomy.

Although there are different methods and criteria for determining 25-OH D3 levels, the criteria suggested by Holic have been widely accepted. In this recommendation, 25-OH D3 deficiency is called as deficiency if $25-\mathrm{OH}$ D3 level in the circulating blood is $20 \mathrm{ng} / \mathrm{ml}$ (50 $\mathrm{nmol} / \mathrm{L}$ ) and below, is called as partial deficiency if it is between 21 and $29 \mathrm{ng} /$, and is called as adequate if it is greater than or equal to $30 \mathrm{ng} /$ $\mathrm{ml}$. [10]. These values were also taken as basis in our study.

Both prospective and retrospective epidemiological studies show that 25-OH D3 levels below $20 \mathrm{ng} / \mathrm{ml}$ are associated with a $30 \%$ to $50 \%$ increased risk of colon, prostate, and breast cancers and higher mortality in these cancers [11]. In our study, we think that the mean 25-OH D3 levels measured as 30 $\mathrm{ng} / \mathrm{ml}$ in the control group, versus the $20 \mathrm{ng} /$ $\mathrm{ml}$ value measured in patients who underwent thyroidectomy may increase the risk of malignancy.

It has been reported that low serum levels of 25-OH D3 are closely associated with the occurrence of cardiovascular diseases in addition to high cholesterol, smoking, obesity, high blood pressure and diabetes, [12] and it has been shown that 25-OH D3 deficiency is also associated with the development of diabetes [13]. Recent studies have shown that 25-OH D3 levels are negatively associated with diabetes type 2 mellitus, islet beta cell function, insulin resistance, body fat and BMI levels [14].

25-OH D3 plays an important role in immune cell biology, together with 25-OH D3 receptors, in regulating immune function, inhibiting inflammatory reactions and autoimmune diseases [15]. For all these reasons, our results suggest that even if the patients are normocalcemic after thyroidectomy, it is predicted that there may be a decrease in $25-\mathrm{OH}$ D3 levels and that it may need to be replaced.

Hypocalcemia following total thyroidectomy (TT) is a relatively common and sometimes difficult complication to correct. Transient hypocalcemia occurs in $50-68 \%$ of patients after TT, whereas permanent hypocalcemia occurs in 3\% of patients after TT [16]. Transient hypocalcemia is defined by various authors as a decrease in $\mathrm{Ca}$ lasting 6 to 12 months after surgery, and persistent hypocalcemia is a decrease in $\mathrm{Ca}$ after TT lasting more than 12 months [17] In our study, we aimed to investigate whether there is $25 \mathrm{OHD}$ deficiency independent of hypocalcemia by including patients who did not develop temporary or permanent hypocalcemia after thyroidectomy.

Postoperative hypocalcemia is defined as any single corrected Ca level less than $8.0 \mathrm{ng} /$ $\mathrm{mL}$ in the postoperative period. The corrected $\mathrm{Ca}$ is calculated as: Measured $\mathrm{Ca}+0.02 \times(40-$ serum albumin) [18]. The values measured in both groups with the volunteers in our study were normocalcemic $(9.15 \pm 0.50,9.41 \pm 0.48)$.

In the literature, there are no reports stating that most thyroidectomy patients may have 25-OH D3 deficiency without symptoms of hypocalcemia and that these patients can be treated with oral administration of only $\mathrm{Ca}$ and 25-OH D3 preparations, and that isolated 25$\mathrm{OH}$ D3 supplements should be given in these patients [19]. The results of our study suggest that even if other biochemical evaluations are normal, postoperative 25-OH D3 deficiency can be seen.

Griffin et al. [20] reported the incidence of transient biochemical hypocalcemia as $24 \%$ after thyroidectomy, and claimed that there was no correlation between 25-OH D3 levels and the risk of postoperative hypocalcemia. In our study, we found that low 25-OH D3 levels may also be present in normocalcemic patients. These results supports the findings of Griffin et al. [20].

25-OH D3 plays an important role in $\mathrm{Ca}$ metabolism by increasing the absorption of $\mathrm{Ca}$ from the gastrointestinal tract. In patients with 25-OH D3 deficiency after thyroidectomy, secondary hyperparathyroidism is also likely to occur to keep Ca levels normal [21]. Therefore, it is recommended to treat all of these patients as if they have 25-OH D3 deficiency. 
In some recent clinical studies, it has been claimed that there is no relationship between $\mathrm{Ca}$ level and 25-OH D3 level after total thyroidectomy. Yang et al. [22] reported that preoperative 25-OH D3-vitamin level did not affect postoperative $\mathrm{Ca}$ level in patients who underwent total thyroidectomy. In the study conducted by Al Khatib et al. [23], it was reported that low 25-OH D3 level affects the early postoperative $\mathrm{Ca}$ level but not the longterm Ca level in patients who underwent total thyroidectomy. It has also been reported that Ca supplementation with $25-\mathrm{OH}$ D3 is more effective than $\mathrm{Ca}$ supplementation alone in preventing early postoperative hypocalcemia [24]. Chiu et al. [25] reported that long-term 25$\mathrm{OH}$ D3 levels in patients with postmenopausal total thyroidectomy were significantly lower than in the control group, and this caused various complications related to the musculoskeletal system. In our study, postoperative low 25-OH D3 levels were also present, and we observed that 25-OH D3 level did not affect Ca level in the long-term postoperatively. These results are consistent with the results of previous studies.

Hypothyroidism develops in all patients undergoing total thyroidectomy. To prevent this complication, external thyroid hormone replacement is required. It has been reported that it is necessary to keep the TSH hormone within normal range, especially after total thyroidectomy, to prevent the growth of the ectopic thyroid tissue left behind due to hypothyroidism and other clinical conditions [26]. For this, long-term T3 and T4 replacement was recommended to patients, and levothyroxine (LT4) was mostly used for this purpose. In the experimental studies of Jin et al. [27], it was reported that the T4 level was higher in the study groups compared to the healthy group due to LT4 given to prevent hypothyroidism after total thyroidectomy. In the study of Regalbuto et al. [28], it was reported that there may sometimes be subclinical hyperthyroidism due to LT4 administration after total thyroidectomy. The high T4 levels observed in the patient group who underwent thyroidectomy in our study also confirm the results of these experimental and clinical studies.

Limitations of the study: The limitation of our study is the small number of patients and that its being a single-center study. The study was designed retrospectively. Therefore, it was not possible to blindly randomize the study control groups and keep the number of the groups equal. Preoperative 25-OH D3 levels of the patients could not be screened. Therefore, patients with vitamin $D$ deficiency independent of surgery could not be excluded. This study's strength is that while many previous studies have mentioned the results of total thyroidectomy with early 25-OH D3 and $\mathrm{Ca}$, this one is a case-controlled study comparing the long-term results of vitamin 25-OH D3 in patients with normocalcemic total thyroidectomy.

Routine monitoring of $\mathrm{Ca}$ levels alone is not sufficient in the postoperative period in patients who have undergone thyroidectomy for nodular goiter. We think that routine monitoring of 25$\mathrm{OH}$ D3 levels in these patients, even if they are normocalcemic in the postoperative period, and replacing them when necessary will have an important role in preventing hypocalcemia and secondary hyperparathyroidism that may develop in the following period.

Conflict of interest: No conflict of interest was declared by the authors.

\section{References}

1. Dean DS, Gharib H. Epidemiology of thyroid nodules. Best Pract Res Clin Endocrinol Metab 2008;22:901911. https://doi.org/10.1016/j.beem.2008.09.019

2. Paschou SA, Vryonidou A, Goulis DG. Thyroid nodules: a guide to assessment, treatment and followup. Maturitas 2017;96:1-9. https://doi.org/10.1016/j. maturitas.2016.11.002

3. Biello A, Kinberg EC, Wirtz ED. Thyroidectomy. StatPearls [Internet], 2020. Available at: https://www. ncbi.nlm.nih.gov/books/NBK563279/. Accessed September 14, 2021

4. Ciuni R, Biondi A, Di Giunta M, Basile F, Ciuni S. Total thyroidectomy vs subtotal thyroidectomy for plurinodular goiter. Analysis 1517 cases.Ann Ital Chir 2010;81:9-12. Available at: https://europepmc.org/ article/med/20593744. Accessed September 14, 2021

5. Fleet JC. The role of vitamin $\mathrm{D}$ in the endocrinology controlling calcium homeostasis. Mol Cell Endocrinol 2017;453:36-45.https://doi.org/10.1016/j. mce.2017.04.008

6. Sizar O, Khare S, Goyal A, Bansal P, Givler A. Vitamin D deficiency. StatPearls. Treasure Island (FL): StatPearls Publishing LLC.; 2021.

7. Kim D. The role of vitamin $\mathrm{D}$ in thyroid diseases. Int J Mol Sci 2017;18:1949. https://doi.org/10.3390/ ijms18091949 
8. Dağlar G, Kiliç MÖ, Çelik C, et al. Is there a relatlonshlp between vitamin $D$ status and hypocalcemla after total thyroidectomy? Acta Endocrinol (Buchar) 2016;12:291. https://doi.org/10.4183/aeb.2016.291

9. James KB, Haridimos M, Anita S, Cowan M, Fleming B, Palazzo F. Preoperative vitamin $D$ deficiency predicts postoperative hypocalcemia after total thyroidectomy. World J Surg 2011;35:324-330. https://doi.org/10.1007/ s00268-010-0872-y

10. Dawson Hughes B, Heaney RP, Holick MF, Lips P, Meunier PJ, Vieth R. Estimates of optimal vitamin D status. Osteoporos Int 2005;16:713-716. https://doi. org/10.1007/s00198-005-1867-7

11. Giovannucci E, Liu Y, Rimm EB, et al. Prospective study of predictors of vitamin $D$ status and cancer incidence and mortality in men. JNCl 2006;98:451-459. https://doi.org/10.1093/jnci/djj101

12. Lavie CJ, DiNicolantonio JJ, Milani RV, O'Keefe JH. Vitamin D and cardiovascular health. Circulation 2013;128:2404-2406. https://doi.org/10.1161/ circulationaha.113.002902

13. Harinarayan CV. Vitamin $D$ and diabetes mellitus. Hormones (Athens), 2014;13:163-181. Available at: https://link.springer.com/article/10.1007/BF03401332. Accessed September 14, 2021

14. Soo Lim, Min Joo Kim, Soo Lim, et al. Association of vitamin $\mathrm{D}$ deficiency with incidence of type 2 diabetes in high-risk Asian subjects. Am J Clin Nutr 2013;97:524530. https://doi.org/10.3945/ajcn.112.048496

15. Jeffery LE, Qureshi S, David G, et al. Vitamin D Antagonises the Suppressive Effect of Inflammatory Cytokines on CTLA-4 Expression and Regulatory Function. PLoS One 2015;10:131-139. https://doi. org/10.1371/journal.pone.0131539

16. Rosato L, Avenia N, Bernante P, et al. Complications of thyroid surgery: analysis of a multicentric study on 14,934 patients operated on in Italy over 5 years. World J Surg 2004;28:271-276. https://doi.org/10.1007/ s00268-003-6903-1

17. D'Ajello F, Cirocchi R, Docimo G, et al. Thyroidectomy with ultrasonic dissector: a multicentric experience. G Chir 2010;31:289-292. Available at: http://eprints.bice. rm.cnr.it/id/eprint/6897. Accessed September 14, 2021

18. RB Payne, Little AJ, Williams RB, Milner JR. Interpretation of serum calcium in patients with abnormal serum proteins. Br Med J 1973;4:643-646. https://doi.org/10.1136/bmj.4.5893.643

19. Lemaire F, Debruyne F, Delaere P, Poorten V. Parathyroid function in the early postoperative period after thyroidectomy. Acta Otorhinolaryngol Belg 2001;55:187-198. Available at: https://europepmc.org/ article/med/11441478. Accessed September 14, 2021

20. Griffin TP, Murphy MS, Sheahan P. Vitamin D and risk of postoperative hypocalcemia after total thyroidectomy. JAMA Otolaryngol Head Neck Surg 2014;140:346-351. https://doi.org/10.1001/jamaoto.2014.25
21. Yamashita H, Murakami T, Noguchi $S$, et al. Postoperative tetany in Graves disease: important role of vitamin D metabolites. Ann Surg 1999;229:237-245. https://doi.org/10.1097/00000658-199902000-00012

22. Yang X, Guan Y, Yan B, et al. Evidence-based complementary and alternative medicine bioinformatics approach through network pharmacology and molecular docking to determine the molecular mechanisms of Erjing pill in Alzheimerıs disease. Exp Ther Med 2021. https://doi.org/10.3892/etm.2021.10687

23. Al Khatib T, Althubaiti AM, Althubaiti A, et al, Severe vitamin $D$ deficiency: a significant predictor of early hypocalcemia after total thyroidectomy. Otolaryngol Head Neck Surg 2015;152:424-431. https://doi. org/10.1177/0194599814561209

24. Wang TS, Cayo AK, Wilson SD, et al. The value of postoperative parathyroid hormone levels in predicting the need for long-term vitamin D supplementation after total thyroidectomy. Ann Surg Oncol 2011;18:777-781. https://doi.org/10.1245/s10434-010-1377-5

25. Chiu TH, Chen SC, Yu HC, et al. Association between Geriatric Nutrition Risk Index and Skeletal Muscle Mass Index with Bone Mineral Density in Post-Menopausal Women Who Have Undergone Total Thyroidectomy. Nutrients 2020;12:1683. https://doi.org/10.3390/ nu12061683

26. Seitz D, Todt I, Boga E, Yasin A, Sudhof H. Ectopic thyroid tissue after total thyroidectomy. HNO 2020;68:447-450. https://doi.org/10.1007/s00106-01900754-7

27. Jin S, Sugitani I. TSH suppression was induced in rat model after total thyroidectomy. J Nippon Med Sch 2020;21:88-409. https://doi.org/10.1272/jnms. JNMS.2021_88-409

28. Regalbuto C, Maiorana R, Alagona C, et al. Effects of either LT4 monotherapy or LT4/LT3 combined therapy in patients totally thyroidectomized for thyroid cancer. Thyroid 2007;17:323-331. https://doi.org/10.1089/ thy.2006.0084

Ethics committee approval: This study was approved by the local ethics committee under protocol number 2021/74 at Nigde Omer Halisdemir University Medical Faculty Hospital (approval date: 12.08.2021).

\section{Contributions of the authors to the article}

H.B. Consept, Design, materials, data collection, interpretation, literature search, manuscript, writing, critical review. M.K. Consept, materials, data collection, interpretation, literature search, critical review. All authors approved the final version of the manuscript. 